\title{
史上最大の地震
}

\section{The biggest one}

RofF SMITH 2010 年 5 月 6 日号 Vol. 465 (24-25)

これまで観測された史上最大の地震が、

1960 年 5 月に発生した「1960 年チリ地震」だ。

チリ地震から 50 周年を迎えた今、私たちが再認識しなければならないのは、

この巨大地震が地震学にもたらした革命についてである。

1960 年 5 月のある土曜日の早朝、巨大 地震がチリの南部を摇さぶつた。このと き、咓碎の下からはい出すことのできた 幸運な住民たちは、自分たちは自然界が もたらす最悪の災害に見舞われた、と考 えたはずだ。実際、彼らの村を倒壊させ た地震の大きさは、のちにマグニチュー ド 8.1 と見積もられた。これは、過去 1 年余りの間に地球が引き起こした摇れの 中で最大規模のものだった。

首都サンティアゴの当局は、急遽、被 災地に救援隊を派遣した。しかし、これ ほど大きな地震さえも、さらに巨大な地 震の前震にすぎないことを予見するのは 不可能だった。本震は、翌 5 月 22 日の 午後に発生した。激しい摇孔はまさに地 球全体を振動させ、その振動は数日にわ たって続いたのだった。

以来数十年間、地震学者は、チリ地震 がいかに巨大であったかを理解すべく、 当時のさまざまな情報やデー夕を精査し てきた。彼らは地震の規模を測定する全 く新しい方法を考え出し、1960 年のチ リ地震には、対数目盛を用いたマグニ チュードで 9.5 という数值を与えた。こ れは、今日までに記録された地震の中で 最も大きな数值である。

広島を壊滅させた原爆の 2 万倍以上 のエネルギーをもつこの地震は、チリ 国内で少なくとも 1500 人の犠牲者を出 し、高さ 25 メートルの津波を発生させ て沿岸の村々を流し去り、港に停泊して いた船を 1 キロメートル以上も内陸に 打ち上げた。津波は太平洋に波及して八
ワイのヒロで 61 人の命を奪い、さらに 日本に押し寄せた。震央から 1 万 7000 キロメートルも離れた日本では、この地 震による津波を警戒する人はなく、死者 は 142 人に上った。

「南米で発生した地震が、遠く日本で 犠牲者を出したのです」と、南カリフォ ルニア地震センター (米国ロサンゼルス) の Tom Jordan 所長はいう。「まさに、 地球規模のモンスター地震でした」。

2010 年 1 月にハイチを襲つた巨大地 震をはじめ、チリ地震より多くの死者を 出した地震はいくつもある。しかし、発 生から半世紀が経過してもなお、このモ ンスター地震は研究者を魅了し、その 好奇心をかき立て続けている。2010 年 5 月、米国地球物理学連合 (AGU) は、 チリ地震から 50 周年の節目の年に当た り、チリのバルパライソで巨大地震と津 波に関する会議を開いた。多くの代表者 が被災地を訪問し、地震がこの地の景観 に残した傷跡や、津波が置いていった堆 積物に、改めて驚嘆したのだった。

この会議の主催者である米国地質調査 所（ワシントン州シアトル）地震災害予 測チームのBrian Atwater は、「チリ地 震は、近代地震史における最大級の地震 として、地震の規模を評価するための基 準になっています」という。

チリ地震を境に、地震学は大きく様変 わりした。この巨大地震は地震学者に、 地球自由振動に関する最初の明確な証拠 をもたらした。この振動は、鐘をつくと その全体が振動するように、大地震の発

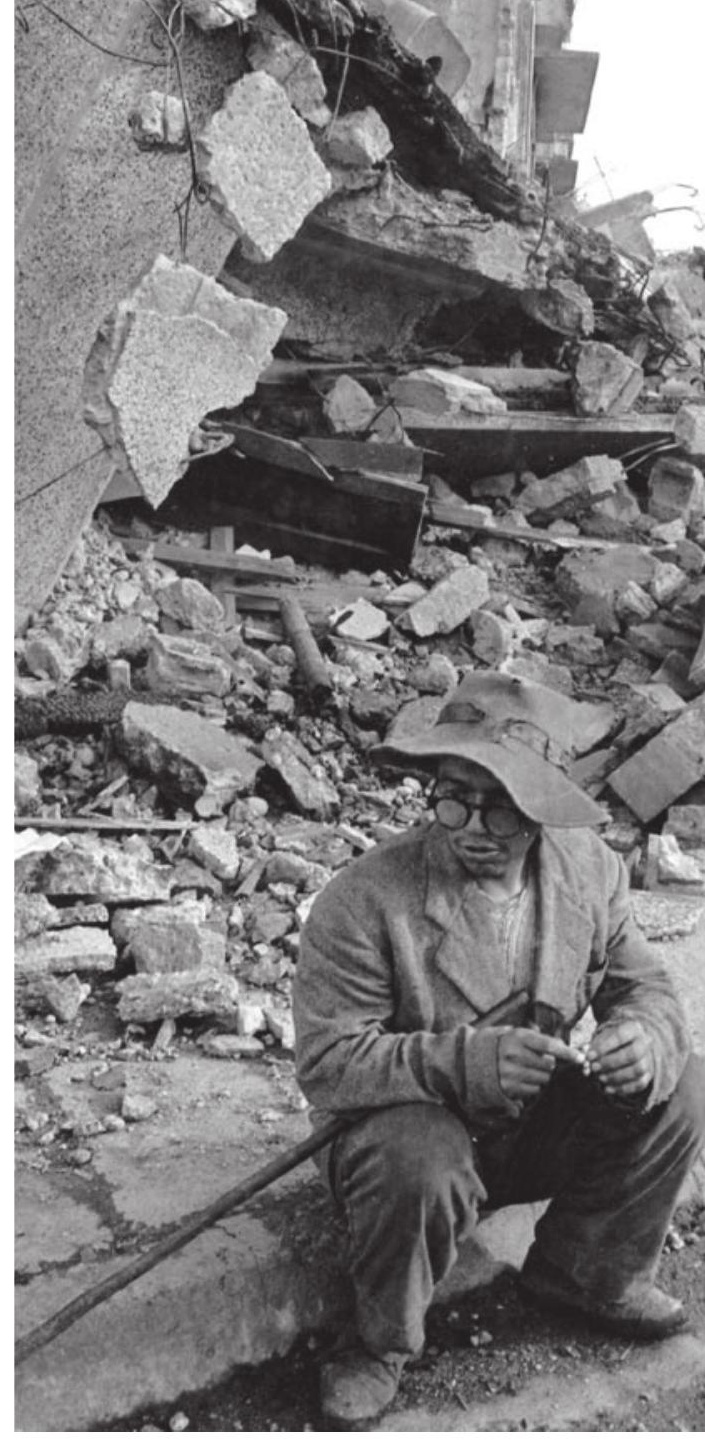

生後、地球全体が調和振動する現象のこ とだ。それから今日まで、研究者たちは こうした自由振動を CT スキャンのよう に利用して、地球の内部構造を理解する 方法を学んできた。

\section{地震が残していったもの}

1960 年のチリ地震と 1964 年に発生し たマグニチュード 9.2 のアラスカ地震 は、プレートが別のプレートの下に潜り 込む場所で発生する「沈み込み帯地震」 の典型的な例だ。これらは、1960 年代 の革命的なプレートテクトニクス理論発 展の基礎となった。

チリ地震は、地球に関する基本的な知 識をもたらしただけではない。1960 年 代に太平洋沿岸諸国で国際的な津波警報 システムが設置されるきっかけとなり、 結果として多くの人命を救うことになつ た。また、地質学者は、津波が残していつ た堆積物を調べることで、巨大地震を引 
1960 年の地震は、チリの海岸線に沿つ て走る断層帯が長さ約 1000 キロメート ルにわたつて破壊されて発生した（下地 図参照)。断層の両側のプレートが互い に 20 〜 30 メートルも滑った結果、数 世紀にわたつて蓄積されてきたエネル ギーが、恐怖の数分間で解放されたのだ。

チリ地震は、単なる史上最大の地震で はない。マグニチュード 9.5 という数值 は、地球が 1 回の地震で解放するエネ ルギーの上限に近いと考えられているの だ。ニューメキシコ鉱業技術研究所（米 国ソコロ）の地球物理学者であり、米国 地震学会の会長である Richard Aster は いう。「将来、チリ地震より大きい地震 が起こる可能性はないといっているわけ ではありません。可能性としてはありま すが、ただし、チリ地震の規模を大幅に 上回るようなことはないでしょう。地震 の規模は、断層の大きさと強度から決 まってくるからです」。

この地震の規模を示すために、Aster は20 世紀に世界中で発生したすべての 地震のエネルギーを合計してみた。これ には、チリの巨大地震のほかに、1952 年のカムチャツカ地震、1964 年のアラ スカ地震など、マグニチュード 9 以上 の地震が含まれている。次に彼は、この エネルギーのすべてが 1 回の地震で解 き放たれたらどうなるか予想してみた。
2004 年に発生したマグニチュード 9.2 のスマトラ島地震を基準にすると、そ れはマグニチュード 9.95 相当の地震に なった。「マグニチュード 10 にはなら ないのです」と Aster はいう。

注目すべきは、100 年余りの間に地球 が解放してきた膨大な地震エネルギーの 合計の、実に 4 分の 1 が、チリ南部カニエ テ付近を震源とするたつた 1 回のチリ地 震で解放されたことだ。観測史上第 2 位 の地震は 1964 年のアラスカ地震だが、 1960 年チリ地震はその 2 倍もあった。

\section{類例のない摇れ}

バルディビアで開かれたチリ地震 50 周 年記念式典には、巨大地震の規模を正確 に測定できるモーメント・マグニチュー ドというスケールの考案にかかわつたカ リフォルニア工科大学 (米国パサディナ) の金森博雄も出席した。地震学の第一人 者として知られる彼は、この 1 年、50 年前のチリ地震のデータの再調査に取り 組んできた。チリ地震のとてつもない規 模だけでなく、その独特な振る舞いにも 興味をもっていたからだ。

最初に発生した前震の大ささを計算し 直した金森は、「マグニチュード 8.1 の 地震が前震にすぎないなんて、いつたい 誰が想像できたでしょう？けれどもそ れは、驚くべき前震系列の始まりにすぎ
き起こすおそれのある場所を特定するた めのモデルを構築することができた。そ の一例が、北米大陸の西海岸のカスカ ディア沈み込み帯である。

とはいえ、チリのモンスター地震の発 生時期は、多くの意味で早過ぎた。地球 科学の技術的・理論的な革命は、まだ始 まったばかりだったからだ。ノースウエ スタン大学 (米国イリノイ州エヴァン ストン）の地震学者 Seth Stein は、「こ の地震の発生時期があと 10 年遅かった ら、はるかに多くのことが明らかになっ ていたでしょう」と語る。チリ地震が発 生した 1960 年には、まだプレートテク トニクスの概念が確立していなかったた め、当時の研究者たちは、この地震を地 球物理学の関連から考察することができ なかった。また、非常に多くの情報をも たらしたに違いない「地震計の広域ネッ トワーク」が設置されたのは、この地震 の 3 年後のことだった。

\section{0 年 5 月 22 日にチリで発生した巨大地震}

マグニチュード 9.5 を記録したこの地震は、太 平洋の海底の一部 (ナスカプレート) が南米プ レートの下に潜り込む「沈み込み帯」に沿って 発生した。2 つのプレートは 1 世紀に約 8 メー トルのペースで収束しており、1575 年には同 じ地域でマグニチュード 8.5 と推測される地震 が発生した。

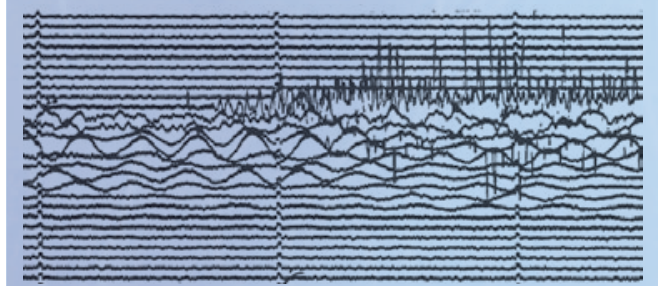

1960年のチリ地震の際に米国カリフォルニア州 バークレーの地震計が記録した摇れ。

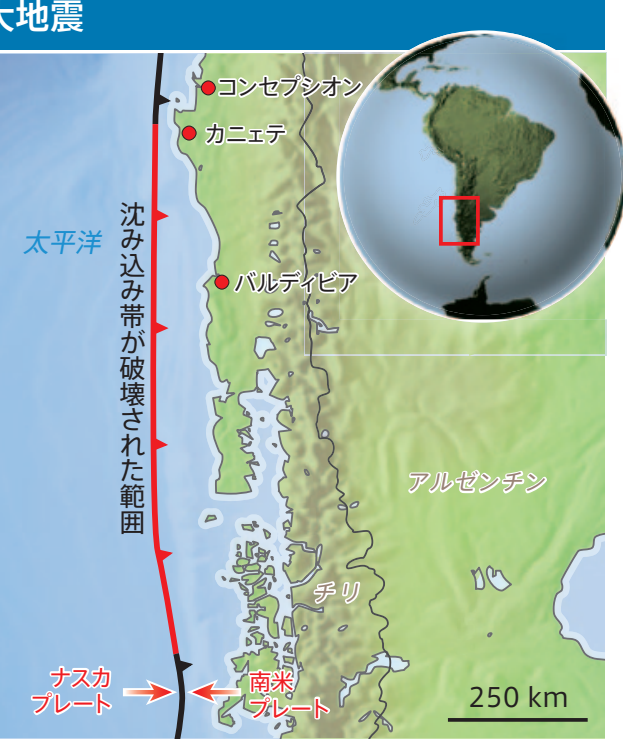


なかったのです」という。彼によると、 本震に当たる巨大地震が発生する 33 時 間前から、マグニチュード 6 以上と推 定される大きな地震が 6 回ほど起き、 わずか 15 分前にはマグニチュード 7.8 の地震が起きたという。「私が知るかぎ り、このような前震系列はほかにはあり ません」。

金森によると、さらに興味深いのは、 本震まで 15 分を切ったときに、パサディ ナの地震計が奇妙な長周期振動を記録し たことだという。この記録は、本震に当 たる巨大地震の前に、地中の深いところ で強い「ゆっくり地震」が発生していた ことを示唆する。この点こそが、チリ地 震を単なる巨大地震とは異なる、類例の ない地震にしているのだ。このような 「ゆっくり地震」は、1944 年に日本で 発生した東南海地震などでも、事前に起 きていたようだが、大きな被害につなが る摇机は生じなかった。断片的な証拠だ けでは、事実を明らかにするよりも、新 たな謎を呼び込んでしまうことが多い。

残念ながら、前震の激しい摇れが、当 時稼㗢していたほかの数台の高性能地震 計の記録を不明瞭にしてしまった。その ため、パサディナの地震計が記録した興 味深い摇孔を裏付ける独立の証拠は存在
しない。しかし、チリでの目撃証言も、 マグニチュード 9.5 の本震の前に異常な 現象が起きていたことを示している。当 時、震央から 200 キロメートルほど離 れたコンセプシオンにいた 2 人の地球 物理学者が、「チ地震は穏やかに摇さ ぶられるような感覚から始まった」と証 言しているのだ。これは、典型的な巨大 地震が突然の激しい摇れから始まるのと は対照的だ。

「彼らの 1 人は、道に停まっていた自 動車が大きく横摇れしているのを目撃 しています」と金森はいう。「巨大地震 の始まりとしては極めて異例の報告です が、訓練された地震学者がこう証言して いる以上、真剣に受け止めなければなり ません」。

1960 年のチリ地震の前に、地中の深 いところで「ゆっくり地震」が本当に発 生していたとすれば、ほかの地域の地震 と関連付けることができる。「多くの科 学者が、カスカディアプレート境界に 沿って巨大な沈み込从帯地震が発生する だろうと考えているのですが、予想され ている地震の始まりのようすが、これと 非常によく似ているのです」と金森はい う。この地域では約 14 か月ごとに「ゆっ くり地震」が発生しているため、一部の
研究者は、カスカディア沈み込み帯はチ リ沖のプレートに似ているのではないか と考えている。

太平洋北西部で巨大地震が発生したと する文書記録は皆無だが、Atwater やほ かの地球科学者は、この地域はマグニ チュード 9 レベルの地震に何度も見舞 われてきたと確信するようになってい る。Atwater らは、1960 年のチリ地震 による津波が残していった砂質堆積物を 調べることで、何世紀も前にカスカディ アで発生した巨大地震による津波が、北 米西部や日本の海岸を襲った痕跡を発見 することができた。

このクラスの巨大地震は、300 年に 1 度か、あるいはもっと低い頻度でしか発 生しないため、研究者が研究対象とする のは困難だ。しかし、現在は地球上の数 百か所に高感度地震計がくまなく設置さ れており、いつでも使えるようになって いる。それゆえ、次のモンスター地震が いつ、どこで発生しても、「1960 年の チリ地震より、はるかによく理解するこ とができるのです」と金森はいう。

(翻訳 : 三枝小夜子)

Roff Smith は英国へースティングズに拠点を置く フリーランスのライター。 